\title{
A New Species: Microcyclus marinus
}

\author{
H. D. RAJ \\ Department of Microbiology, California State University, Long Beach, California 90840
}

For a number of years, only a single species of the genus Microcyclus $\emptyset$ rskov 1928 , namely $M$. aquaticus Orskov, was reported in the literature. Eventually, two more species, $M$. major Gromov 1963 and $M$. flavus Raj 1970, were named and described. Brief mention was also made in the literature of a marine Microcyclus strain (Raj 1970) originally isolated in 1966 from the Pacific Ocean and tentatively, hence not validly, named $M$. marinus. To establish its taxonomic status, the marine isolate was studied extensively and compared with $M$. aquaticus ATCC 25396 and $M$. flavus ATCC 23276, both from freshwater habitats. On the basis of its similarity index, as determined by numerical taxonomy with these previously named species, the marine microcyclus is believed to belong to a new species, for which the name Microcyclus marinus is proposed. The type strain of $M$. marinus has been deposited in the American Type Culture Collection under the number 25205 and in the Deutsche Sammlung von Mikroorganismen Collection under the number 745 .

Although ring-forming bacteria were reported by Weibel in 1887 (35) and by Migula in 1894 and $1900(24,25)$ it was not until 1928 that scientific names were proposed for these organisms. At that time, Orskov (27) introduced the generic name Microcyclus and the specific name Microcyclus aquaticus for these organisms. After a gap of about three decades, various reports of new ring-forming isolates, mostly from soil and water habitats, were made by investigators from different countries: these included Hallock's Vibrio alternans (13), Gromov's Microcyclus major (12), Raj's Microcyclus flavus, and a marine microcyclus, tentatively and therefore not validly named $M$. marinus (5, 29), Claus' Spirosoma strains (7), Nikitin's Renobacter vacuolatum (26), Van Ert's gas-vacuolated Microcyclus aquaticus strains (34), and additional gas-vacuolated strains and a motile, flagellated variant (17; A. E. Konopka, R. L. Moore, and J. T. Staley, personal communication, 1975). Common to all of these gram-negative bacteria is, under suitable cultural conditions, their characteristic closedring-like morphology, as implied by the generic name. Such bacterial forms seem to be widespread in nature, as is documented by a recent scanning electron microscope study of the microbial flora in oceans (30). These "doughnutshaped" bacteria have aroused much interest, and reports concerning their morphogenesis (29; R. G. Freedman and H. D. Raj, Abstr. Annu. Meet. Am. Soc. Microbiol. 1975, I53, p. 125), deoxyribonucleic acid (DNA) base compositions (8), DNA base-sequence homology for genetic relatedness (Konopka et al., personal communication, 1975), gas-vesicle assembly (17), metabolic pathways and enzymes (18), and taxonomy $(5,8,29)$ have appeared in the literature in recent years.

The marine microcyclus tentatively named $M$. marinus but not described by the author in 1970 (29) is described and compared extensively with the two currently recognized species $M$. aquaticus and $M$. flavus in order to establish its taxonomic status.

\section{MATERIALS AND METHODS}

Morphological and cultural studies. M. aquaticus American Type Culture Collection (ATCC) strain 25396 and $M$. flavus ATCC 23276 were grown and maintained as slant cultures on tryptone glucose extract agar (Difco) medium made with distilled water and fortified with $0.1 \%$ yeast extract (TGEY). A marine bacterium was originally isolated (29) from a Dendraster (sand dollar) off the Pacific Coast in Newport Beach, Calif., during the summer of 1966 , and a culture of this isolate was deposited in the ATCC under the number 25205. It was grown and maintained on modified Zobell $2216(\mathrm{mZ}) \mathrm{me}$ dium containing peptone $(0.5 \mathrm{~g})$, yeast extract $(0.1$ $\mathrm{g})$, ferrous sulfate $(0.02 \mathrm{~g})$, agar $(2.0 \mathrm{~g})$, and seawater $(100 \mathrm{ml})$. These three bacteria were incubated at room temperature $\left(20\right.$ to $25^{\circ} \mathrm{C}$ ) for growth and were maintained at refrigeration temperature (approximately $7^{\circ} \mathrm{C}$ ), with subculturing every 3 weeks. Young cultures of these bacteria grown in their respective media, as described above, were used to study their morphology and cultural characteristics (Tables 1 and 2).

Electron microscopy. For scanning electron microscopy, exponentially grown cells of the marine isolate were harvested from an $\mathrm{mZ}$ agar slant and transferred directly into $3 \%$ glutaraldehyde in 10 $\mathrm{mM} \quad N$-2-hydroxyethylpiperazine- $N^{\prime}$-2-ethanesul- 
TABLE 1. Morphological characteristics of the strains studied ${ }^{a}$

\begin{tabular}{|c|c|c|c|}
\hline Characteristic & $\begin{array}{l}\text { Marine isolate }^{b} \\
\text { ATCC } 25205\end{array}$ & $\begin{array}{c}M . \text { flavus }^{c} \\
\text { ATCC } 23276\end{array}$ & $\begin{array}{l}\text { M. aquaticus } \\
\text { ATCC } 25396^{c}\end{array}$ \\
\hline 1. Unicellular cells & + & + & + \\
\hline 2. Curved rods (vibrio-like) & $\perp$ & $\perp$ & + \\
\hline 3. Curved rods (horseshoe-like) & + & + & $\perp$ \\
\hline 4. Closed ring-like cells & + & + & $\perp$ \\
\hline 5. Coils or spiral forms & + & + & - \\
\hline $\begin{array}{l}\text { 6. Maximum cell size (width }<1.0, \text { OD }^{d}<2.0 \text {, length }< \\
5.0 \mu \mathrm{m} \text { ) }\end{array}$ & + & - & + \\
\hline 7. Filamentous forms & $+^{e}$ & $+^{e}$ & - \\
\hline 8. Pleomorphic forms & - & - & $+^{e}$ \\
\hline 9. Cells with rounded ends & + & + & + \\
\hline 10. Cells with pointed ends & - & - & - \\
\hline 11. Cells mostly single & + & + & + \\
\hline 12. Some cells in pairs or chains & - & - & - \\
\hline 13. Branching cells & - & - & - \\
\hline 14. Sheathed cells & - & - & - \\
\hline 15. Flagellated cells & - & - & - \\
\hline 16. Nonmotile cells & + & + & + \\
\hline 17. Common capsule for aggreated cells & - & + & + \\
\hline 18. Cells individually encapsulated & - & + & + \\
\hline 19. Cyst or zoogloea & - & - & - \\
\hline 20. Gas vacuolation & - & - & + \\
\hline 21. Gram-negative cells & + & + & + \\
\hline 22. Cells with giemsa stain & + & + & + \\
\hline $\begin{array}{l}\text { No. of total morphological similarities with the marine } \\
\text { isolate }\end{array}$ & & 19 & 13 \\
\hline $\begin{array}{l}\text { No. of positive morphological similarities with the marine } \\
\text { isolate }\end{array}$ & & 11 & 7 \\
\hline $\begin{array}{l}\text { No. of morphological dissimilarities with the marine iso- } \\
\text { late }\end{array}$ & & 3 & 9 \\
\hline
\end{tabular}

${ }^{a}$ Symbols: + , the most common morphological feature seen; $\perp$, relatively less common morphological feature seen.

${ }^{b}$ Grown on $\mathrm{mZ}$ agar medium at room temperature.

c Grown on TGEY agar medium at room temperature.

a Abbreviation: OD, outer diameter.

$e$ Morphological feature seen under certain cultural conditions only.

fonic acid (HEPES) buffer (pH 7.0) at $23^{\circ} \mathrm{C}$. The cells were immediately collected on a $0.22-\mu \mathrm{m}$ membrane filter (Millipore Corp.) and fixed by immersion in 1\% $\mathrm{OsO}_{4}$ in $4 \mathrm{mM}$ potassium phosphate buffer containing $1 \mathrm{mM} \mathrm{CaCl}_{2}$ (pH 7.0). The cells were then dehydrated by increasing concentrations of ethanol and dried by the critical-point method. Microscopy was carried out with an AMR-1000A scanning electron microscope at $20 \mathrm{kV}$ with a 2-degree specimen tilt.

For transmission electron microscopy, cells of the marine isolate, harvested as above, were fixed in $3 \%$ glutaraldehyde in $10 \mathrm{mM}$ HEPES buffer $(\mathrm{pH} 7.0)$ for $1.5 \mathrm{~h}$ at $0^{\circ} \mathrm{C}$. The cells were then centrifuged at 7,000 $\times g$ for $5 \mathrm{~min}$ and suspended in $1 \% \mathrm{OsO}_{4}$ in the above-mentioned phosphate buffer for $4 \mathrm{~h}$ at $0^{\circ} \mathrm{C}$. The cells were then dehydrated in increasing concentrations of ethanol and embedded in araldite. Ultrathin sections (silver to gray) were cut with a diamond knife on a Reichert ultramicrotome, poststained with uranyl acetate and lead citrate, and micrographed with a Phillips 300 TEM.

Physiological studies. To determine the optimum growth temperature, cultures of the organisms were inoculated in their respective media, described above, and incubated at 7,20 to 25,37 , and $45^{\circ} \mathrm{C}$. For determination of the $\mathrm{pH}$ which affords optimum growth, the above-mentioned media were adjusted to $\mathrm{pH}$ 5.0 through pH 9.0. For heat-sensitivity determinations, cultures were exposed to 55,80 , and $95^{\circ} \mathrm{C}$ for $10 \mathrm{~min}$, and for disintecting effect they were exposed to $70 \%$ ethanol, $3 \% \mathrm{H}_{2} \mathrm{O}_{2}$, and $0.1 \%$ Zepharin chloride at intervals between 2.5 and $15 \mathrm{~min}$. After each exposure, loopfuls of test culture were transported into the growth medium and incubated. For osmotic effect, the above-mentioned media with 5 to $20 \%$ sucrose were used. For growth in the presence of $\mathrm{NaCl}$, TGEY broth tubes containing 0 to $20 \%$ $\mathrm{NaCl}$ were inoculated. The bactericidal effect of ultraviolet (UV) irradiation was determined by exposures to $25-\mathrm{W}$ Hanovia 8341 at a $1-\mathrm{ft}(30.48-\mathrm{cm})$ distance for up to $3.0 \mathrm{~min}$. Various commercially available media (nonselective, selective, and chemically defined), as listed in Table 3, were tested for supporting the growth of these doughnut-shaped bacteria. For the marine isolate, the media were fortified so as to contain $3 \% \mathrm{NaCl}$ and $0.03 \% \mathrm{~K}_{2} \mathrm{HPO}_{4}$. Also, 
INT. J. Syst. Bacteriol.

TABLE 2. Cultural characteristics, on substrates $m Z$ and TGEY (agar and broth), of the strains studied

\begin{tabular}{cccc}
\hline & Marine isolate & M. flavus & M. aquaticus \\
Characteristic & ATCC 25205 & ATCC 23276 & ATCC 25396 \\
& $(\mathrm{mZ})^{a}$ & (TGEY) $^{a}$ & (TGEY) $^{a}$ \\
\hline
\end{tabular}

Surface colony (agar):
23. A. Form:

24.

25 .

26.

27.

Circular

Irregular

Spindle

Filamentous

28. B. Elevation:

Rhizoid

29.

Flat

30.

31.

32.

33.

Raised

Convex

Pulvinate

Concave

34. C. Margin:

Umbonate

35.

Entire

36.

37.

38.

39.

40.

Undulate

Lobate

Erose

Filamentous

Curled

41. D. Size:

Granular

42.

Punctiform

43.

Small $(<2 \mathrm{~mm})$

Medium (2-5 mm)

44.

Large (> $5 \mathrm{~mm}$ )

45. E. Color:

White

46.

Off-white

Grayish

48.

49.

Yellowish

50.

51.

52.

53.

54.

55.

Pinkish

Mucoid

Dull

Opaque

Transparent

Contoured

Smooth

$\begin{array}{ll}+ & + \\ - & - \\ - & -\end{array}$

$\begin{array}{ll}+ & + \\ - & - \\ - & -\end{array}$

Broth culture:

56. G. Surface growth: Ring

57.

Pellicle

$\begin{array}{ll}\text { 58. H. Turbidity: } & \text { Even } \\ \text { 59. } & \text { Flocculent }\end{array}$

60. I. Sediment:

61 .

Flaky or granular Viscid

$$
\begin{aligned}
& - \\
& - \\
& + \\
& - \\
& -
\end{aligned}
$$

$\begin{array}{lll}+ & + \\ - & - & -\end{array}$

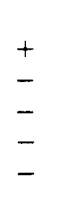


TABLE 3. Physiological characteristics of the strains studied ${ }^{a}$

\begin{tabular}{|c|c|c|c|}
\hline Growth characteristic & $\begin{array}{l}\text { Marine isolate }^{a} \\
\text { ATCC } 25205\end{array}$ & $\begin{array}{c}M . \text { flavus } \\
\text { ATCC } 23276\end{array}$ & $\begin{array}{l}\text { M. aquaticus } \\
\text { ATCC } 25396\end{array}$ \\
\hline 62. At $7^{\circ} \mathrm{C}$ & $\perp$ & $\perp$ & $\perp$ \\
\hline 63. At $20-25^{\circ} \mathrm{C}$ & + & + & + \\
\hline 64. At 37 and $45^{\circ} \mathrm{C}$ & - & - & - \\
\hline 65. $\mathrm{pH} 5.0$ & - & $\perp$ & - \\
\hline 66. $\mathrm{pH} 6.0$ & $\perp$ & $\perp$ & $\perp$ \\
\hline 67. $\mathrm{pH} 7.0$ & + & + & + \\
\hline 68. $\mathrm{pH} 8.0$ & + & $\perp$ & $\perp$ \\
\hline 69. $\mathrm{pH} 9.0$ & $\perp$ & - & $\perp$ \\
\hline 70. In presence of $0 \% \mathrm{NaCl}$ & $\perp$ & + & + \\
\hline 71. In presence of $1.5 \% \mathrm{NaCl}$ & + & $\perp$ & + \\
\hline 72. In presence of $3.0 \% \mathrm{NaCl}$ & + & $\perp$ & $\perp$ \\
\hline 73. In presence of $5.0 \% \mathrm{NaCl}$ & + & - & - \\
\hline 74. In presence of $10.0 \% \mathrm{NaCl}$ & $\perp$ & - & - \\
\hline 75. In presence of $15.0 \% \mathrm{NaCl}$ & $\perp$ & - & - \\
\hline 76. In presence of $20.0 \% \mathrm{NaCl}$ & - & - & - \\
\hline 77. In presence of $5.0 \%$ sucrose & - & - & - \\
\hline 78. In presence of $10.0 \%$ sucrose & - & - & - \\
\hline 79. In presence of $15.0 \%$ sucrose & - & - & - \\
\hline 80. In presence of $20.0 \%$ sucrose & - & - & - \\
\hline 81. After 10 -min exposure at $55^{\circ} \mathrm{C}$ & + & $\perp$ & $\perp$ \\
\hline 82. After 10 -min exposure at $80^{\circ} \mathrm{C}$ & - & - & - \\
\hline 83. After 10 -min exposure at $95^{\circ} \mathrm{C}$ & - & - & - \\
\hline 84. After 0.5 -min exposure to UV & - & + & - \\
\hline 85. After 1.0 -min exposure to UV & - & + & - \\
\hline 86. After $3.0-\mathrm{min}$ exposure to UV & - & - & - \\
\hline 87. After 2.5 -min exposure to $70 \%$ ethanol & - & - & - \\
\hline 88. After 2.5 -min exposure to $3 \% \mathrm{H}_{2} \mathrm{O}_{2}$ & - & - & - \\
\hline $\begin{array}{l}\text { 89. After } 2.5 \text {-min exposure to } 0.1 \% \text { zephar- } \\
\text { ine chloride }\end{array}$ & - & - & - \\
\hline 90. Brain heart infusion broth (Difco) & + & $\perp$ & + \\
\hline 91. Trypticase soy broth (BBL) & + & $\perp$ & + \\
\hline 92. Fluid thioglycolate medium (Difco) & - & - & - \\
\hline 93. Nutrient broth or agar (Difco) & $\perp$ & $\perp$ & + \\
\hline 94. Modified Zobell 2216 medium & + & $\perp$ & $\perp$ \\
\hline 95. Tryptone glucose extract medium (Difco) & + & + & + \\
\hline 96. Blood agar (Difco) & + & + & + \\
\hline 97. Mueller-Hinton agar (BBL) & + & + & + \\
\hline $\begin{array}{l}\text { 98. Cystine trypticase agar with glucose } \\
\text { (BBL) }\end{array}$ & + & + & + \\
\hline 99. Lowenstein-Jensen agar (BBL) & - & - & + \\
\hline 00. Eosin methylene blue agar (Difco) & + & - & + \\
\hline 01. Triple sugar iron agar (Difco): slant/stub & Yellow/yellow & Yellow/yellow & pink/no change \\
\hline 02. Tissue culture medium 199 or L15 (Difco) & + & + & + \\
\hline 03. Brock's synthetic seawater medium & + & $\perp$ & $\perp$ \\
\hline $\begin{array}{l}\text { No. of total physiological similarities with the } \\
\text { marine isolate }\end{array}$ & & 25 & 30 \\
\hline $\begin{array}{l}\text { No. of positive physiological similarities with } \\
\text { the marine isolate }\end{array}$ & & 12 & 14 \\
\hline $\begin{array}{l}\text { No. of physiological dissimilarities with the } \\
\text { marine isolate }\end{array}$ & & 17 & 12 \\
\hline
\end{tabular}

a Symbols: +, Good growth; $\perp$, slight growth; - , no growth even after 35 days of incubation.

${ }^{b}$ Media other than the marine medium used for the marine isolate were fortified with $3.0 \% \mathrm{NaCl}$ and $0.03 \% \mathrm{~K}_{2} \mathrm{HPO}_{4}$.

various antibiotic and sulfonamide-susceptibility tests were performed as described in Table 4.

Biochemical studies. The biochemical methods used in this study were described previously (29) except that, for the marine isolate, the media used were fortified with $3.0 \% \mathrm{NaCl}$ and $0.03 \% \mathrm{~K}_{2} \mathrm{HPO}_{4}$. For detecting the utilization of various carbon sources, a basal medium having the composition of 
TABLE 4. Antibiotic and sulfonamide susceptibilities of the strains studied ${ }^{a}$

\begin{tabular}{|c|c|c|c|}
\hline Antimicrobial agent & $\begin{array}{c}\text { Marine isolate } \\
\text { ATCC } 25205\end{array}$ & $\begin{array}{c}\text { M. flavus } \\
\text { ATCC } 23276\end{array}$ & $\begin{array}{r}\text { M. aquaticus } \\
\text { ATCC } 25396 \\
\end{array}$ \\
\hline 104. Ampicillin $(10 \mu \mathrm{g})$ & + & $1+$ & + \\
\hline 105. Aureomycin $(30 \mu \mathrm{g})^{b}$ & - & $2+$ & $1+$ \\
\hline 106. Bacitracin (10 units) & - & + & - \\
\hline 107. Chloramphenicol $(30 \mu \mathrm{g})$ & $1+$ & $1+$ & - \\
\hline 108. Cephalothin $(30 \mu \mathrm{g})$ & + & + & + \\
\hline 109. Colymycin $(10 \mu \mathrm{g})$ & - & - & - \\
\hline 110. Deelomycin $(30 \mu \mathrm{g})^{b}$ & - & $1+$ & $2+$ \\
\hline 111. Dihydrostreptomycin $(10 \mu \mathrm{g})^{b}$ & - & + & + \\
\hline 112. Elkosin $(50 \mu \mathrm{g})^{b}$ & - & + & - \\
\hline 113. Erythromycin $(15 \mu \mathrm{g})$ & $2+$ & + & + \\
\hline 114. Furadantin $(300 \mu \mathrm{g})^{b}$ & $2+$ & + & + \\
\hline 115. Furadantin + macrodantin $(300 \mu \mathrm{g})$ & $2+$ & + & + \\
\hline 116. Gantrisin $(0.25 \mathrm{mg})$ & - & $2+$ & - \\
\hline 117. Kanamycin $(30 \mu \mathrm{g})$ & - & + & $1+$ \\
\hline 118. Kynex $(1 \mu \mathrm{g})$ & - & + & - \\
\hline 119. Lincomycin $(2 \mu \mathrm{g})$ & $1+$ & - & - \\
\hline 120. Methicillin $(5 \mu \mathrm{g})$ & - & - & - \\
\hline 121. Nalidixic acid $(30 \mu \mathrm{g})$ & + & $1+$ & + \\
\hline 122. Neomycin $(30 \mu \mathrm{g})^{b}$ & - & - & + \\
\hline 123. Novobiocin $(30 \mu \mathrm{g})^{b}$ & $2+$ & $1+$ & $1+$ \\
\hline 124. Oleandomycin $(15 \mu \mathrm{g})$ & $2+$ & + & - \\
\hline 125. Oxacillin $(1 \mu \mathrm{g})$ & - & - & - \\
\hline 126. Penicillin G (10 U) & - & - & - \\
\hline 127. Polymyxin B (50 U) & - & - & - \\
\hline 128. Ristocetin $(30 \mu \mathrm{g})^{b}$ & + & + & - \\
\hline 129. Streptomycin $(5 \mu \mathrm{g})$ & - & + & + \\
\hline 130. Streptomycin $(10 \mu \mathrm{g})$ & - & + & + \\
\hline 131. Sulfadiazine ( $1 \mathrm{mg})$ & - & - & - \\
\hline 132. Sulfamerazine $(50 \mu \mathrm{g})^{b}$ & - & + & - \\
\hline 133. Sulfamethoxy-pyridazine $(50 \mu \mathrm{g})^{b}$ & - & + & - \\
\hline 134. Sulfathiozole (1 mg) & + & $2+$ & - \\
\hline 135. Terramycin $(30 \mu \mathrm{g})^{b}$ & $1+$ & $1+$ & $2+$ \\
\hline 136. Tetracycline $(5 \mu \mathrm{g})$ & - & + & $2+$ \\
\hline 137. Tetracycline $(30 \mu \mathrm{g})$ & + & $1+$ & $2+$ \\
\hline 138. Thiosulfil $(50 \mu \mathrm{g})^{b}$ & - & $1+$ & - \\
\hline 139. Triple sulfa $(0.25 \mathrm{mg})$ & - & - & - \\
\hline 140. Vibramycin $(30 \mu \mathrm{g})$ & - & $1+$ & $2+$ \\
\hline No. of total similarities with marine isolate & & 21 & 23 \\
\hline No. of positive similarities with marine isolate & & 13 & 9 \\
\hline No. of dissimilarities with marine isolate & & 16 & 14 \\
\hline
\end{tabular}

a Symbols: + , susceptible (10- to $20-\mathrm{mm}$ diameter zone of inhibition); -, resistant; $1+$, very susceptible (zone $>20-\mathrm{mm}$ diameter) and $2+$, extremely susceptible (zone $>40-\mathrm{mm}$ diameter). For taxonomic purposes, $1+$ and $2+$ have same weight as + .

${ }^{b}$ Difco disks used; all others were BBL disks. Mueller-Hinton agar medium (BBL) was used in all cases, except that it was fortified with $3.0 \% \mathrm{NaCl}+0.03 \% \mathrm{~K}_{2} \mathrm{HPO}_{4}$ for the marine isolate, and was incubated at room temperature.

Simmons citrate agar (Difco), but without citrate, was supplemented with an equal volume of $0.2 \%$ yeast extract when used for cultures of $M$. aquaticus and $M$. flavus and with an equal volume of the $\mathrm{mZ}$ agar medium when used for the marine isolate. In both cases, the final concentration of carbon source added was $0.1 \%$, except for the controls, to which no carbon source was added. For the determination of the metabolism of carbohydrates by $M$. aquaticus and $M$. flavus, Hugh and Leifson (HL) medium was used in duplicate tubes: one for oxidative reaction, the other for fermentative reaction (overlaid with a layer of sterile mineral oil) (15). For the marine isolate, modified $\mathrm{HL}$ medium containing peptone $(0.2 \%)$, yeast extract $(0.1 \%), \mathrm{NaCl}(3.0 \%), \mathrm{K}_{2} \mathrm{HPO}_{4}$ $(0.03 \%)$, bromothymol blue $(0.008 \%)$, and agar $(0.4 \%)$ ( $\mathrm{pH} 7.8)$ was used. The guanine plus cytosine $(\mathrm{G}+\mathrm{C})$ content of the DNA was determined by the buoyant density-CsCl method described by Mandel (22).

Radiorespirometric studies. The marine isolate was grown in Brock synthetic seawater medium (4) 
at room temperature. The preparation of the cells and the apparatus, the analytical procedures, and the specifically labeled $\left[{ }^{14} \mathrm{C}\right]$ glucoses used were essentially the same as reported previously $(18,28)$ except that $\left[3{ }^{14} \mathrm{C}\right]$ glucose (specific activity, $10 \mathrm{mCi}$ / $\mathrm{mmol}$ ) obtained from the New England Nuclear Corp. was employed in this study. All radiochemical recoveries were then calculated to a total of $100 \%$ in each case of the specifically labeled carbons before the respiratory ${ }^{14} \mathrm{CO}_{2}$ recoveries were used to estimate the percent participation of each pathway involved in the metabolism of an organism. The relative contributions of the Embden-Meyerhof (EM) pathway, the Entner-Doudoroff (ED) pathway, and the pentose phosphate (PP) pathway to carbohydrate catabolism are thus calculated from the percent ${ }^{14} \mathrm{CO}_{2}$ recoveries of glucose carbons by the following set of formulas (H. D. Raj and A. H. Smith. Abstr. Annu. Meet. Am. Soc. Microbiol. 1974, p. 63, p. 155):

$$
\begin{aligned}
& \% \mathrm{PP}=\mathrm{C}_{1}+\mathrm{C}_{3}-\mathrm{C}_{4}-\mathrm{C}_{6} \\
& \% \mathrm{EM}=\frac{\mathrm{C}_{3}-\mathrm{C}_{6}}{\mathrm{C}_{4}-\mathrm{C}_{6}}(1-\% \mathrm{PP}) \\
& \% \mathrm{ED}=\frac{\mathrm{C}_{4}-\mathrm{C}_{3}}{\mathrm{C}_{4}-\mathrm{C}_{6}}(1-\% \mathrm{PP})
\end{aligned}
$$

where each numeral subscript indicates the specific position of a carbon (C) atom in the substrate molecule, each $\mathrm{C}$ represents percent recovery as $\mathrm{CO}_{2}$ and where $\mathrm{C}_{4}=2\left(\mathrm{C}_{3}, 4\right)-\left(\mathrm{C}_{3}\right)$.

\section{RESULTS}

The marine isolate is described and has been compared morphologically, culturally, physiologically, and biochemically with the two recognized species $M$. aquaticus and $M$. flavus (which, unless indicated otherwise, refer to strains ATCC 25396 and ATCC 23276, respectively) as follows.

Morphological characteristics. Cells of the marine isolate are consistently nonmotile, nonflagellated, and gram negative; they occur singly and have the appearance of closed rings ( 0.9 to $1.5 \mu \mathrm{m}$ outer diameter) with hollow centers $(0.3$ to $0.6 \mu \mathrm{m}$ diameter $)$ or of "horseshoes" ( 0.8 to $1.3 \mu \mathrm{m}$ outer diameter and 0.3 to $0.7 \mu \mathrm{m}$ cell width); some curved or straight rods ( 0.3 to $0.6 \mu \mathrm{m}$ wide and 1 to $5 \mu \mathrm{m}$ long) with rounded ends also occur (see Fig. 1, 2 , and 3). Spiral forms and coils of 10 or more cells are common. The electron micrographs clearly show that the ends of a doughnutshaped cell are not completely joined; sometimes they are positioned one over the other. In some cells, an indentation representing a site of cell division is seen. These cells have never been seen with pointed ends, branches, sheaths, capsules, zoogloeae, cysts, spores, or gas vacuoles (Table 1). Morphologically, the marine isolate resembles $M$. flavus since both characteristically form doughnuts, horseshoes, and coils, whereas $M$. aquaticus is more like a vibrio as it does not commonly form ring-like structures and has never been observed to make spirals or coils (29). However, the dimensions of cells of the marine isolate are about half those of $M$. flavus (doughnutand horseshoe-like cells: 1.5 to $3.0 \mu \mathrm{m}$ outer diameter, and 0.4 to $1.0 \mu \mathrm{m}$ hole diameter; rod-like cells: 0.6 to $1.2 \mu \mathrm{m}$ wide and 3.0 to 10.0 $\mu \mathrm{m}$ long) and about the same as those of $M$. aquaticus (doughnut- and horseshoe-like cells: 0.7 to $1.3 \mu \mathrm{m}$ outer diameter, and 0.1 to $0.3 \mu \mathrm{m}$ hole diameter; rod-like cells: 0.4 to $0.7 \mu \mathrm{m}$ wide and 1.0 to $3.0 \mu \mathrm{m}$ long). Unlike the marine isolate and $M$. flavus, $M$. aquaticus shows gas vacuolation; somehow this was overlooked by the author in his previous report on $M$. aquaticus, but it can be seen on close examination of the electron micrographs of this organism published earlier (28). Furthermore, $M$. aquaticus is usually nonmotile; however, a flagellated variant of this organism was recently isolated (17).

Electron micrographs of thin sections of the marine isolate (Fig. 2) show the fine structural features of procaryotic cells in general and terrestrial gram-negative bacteria in particular, especially with regard to cell wall envelope, cytoplasmic granularity, and DNA fibrils. The cell wall of the marine isolate seems to consist of three layers which run unparallel to the more nearly planar cytoplasmic membrane. Although an undulant cell wall is characteristic of most gram-negative bacteria, the extent of undulation, which is slight in this case, varies from organism to organism (36). The cytoplasmic matrix seems to be loosely and randomly packed with densely stained particles of ribonucleoprotein. The DNA is axially disposed and consists of a network of fine fibrils. Similar fine structural features were observed in $M$. flavus (29). Contrary to $0 \mathrm{r}$ skov's observations of $M$. aquaticus, septation for cell division is seen in the marine isolate (Fig. 1 and 2) and in M. flavus (29); however, it remains conjectural whether the mode of binary fission in these organisms is similar to that of other gram-negative bacteria (11). Structures similar to the blebs observed in several gram-negative bacteria (36) were also found in some electron microscope preparations of cells of the marine isolate. It seems that such structures represent cell wall evaginations due to an osmotic imbalance that results in the leakage of cytoplasmic material through "the pores" in the mucopeptide cell 


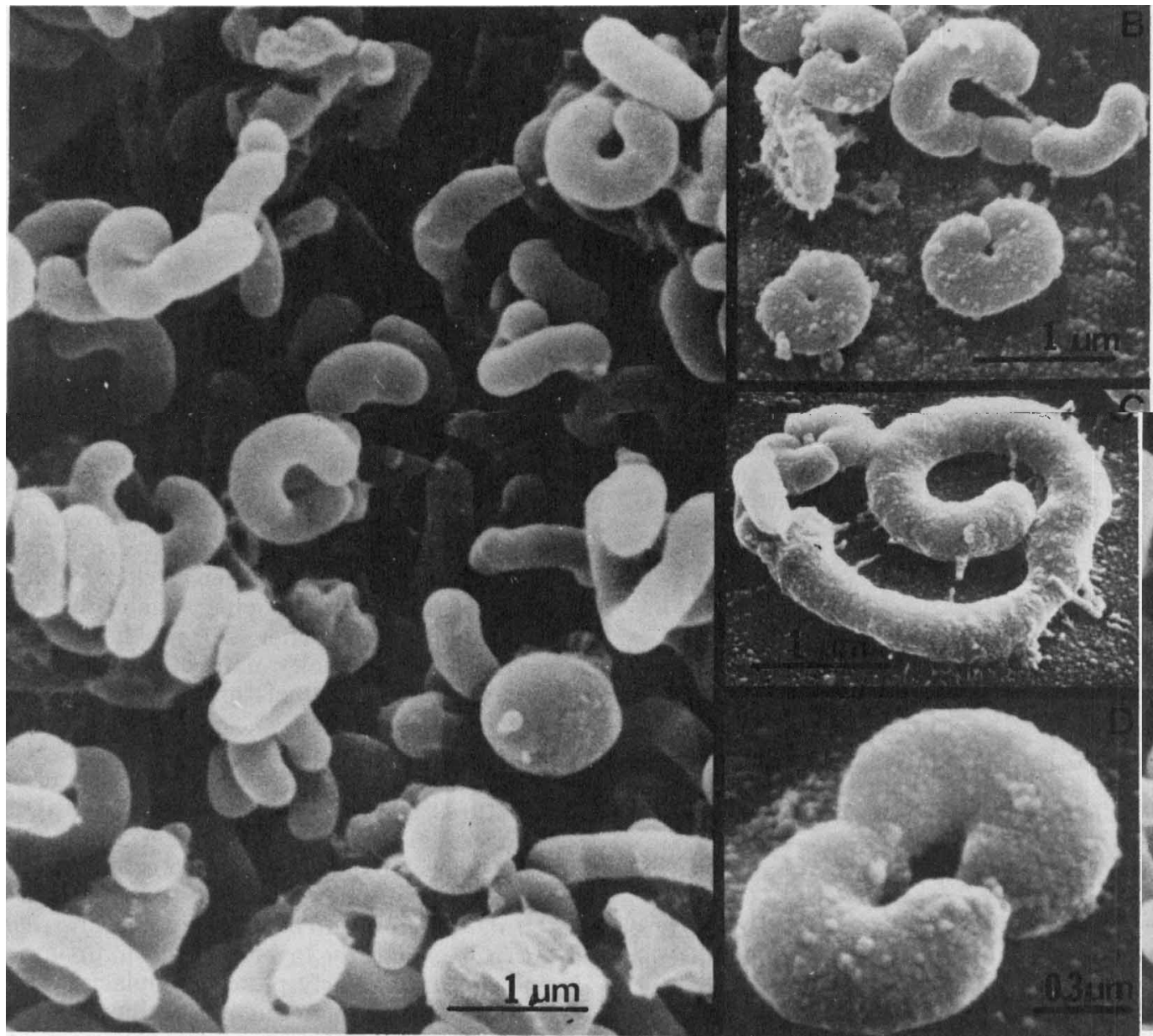

FIG. 1. Scanning electron micrographs of the marine isolate (Raj) showing doughnuts, horseshoes, and coils when grown on $\mathrm{mZ}$ marine medium at $R T$. The cells were washed $(A)$ or not washed $(B, C$, and $D)$ prior to electron microscopy.

wall layer, thereby protruding the outer wall layer, which is rather elastic (1).

Morphological variation is seen in these organisms under different cultural conditions. For example, $M$. aquaticus shows pleomorphic forms when cultures are old, grown in the presence of an oxidizable carbohydrate, or incubated at $7^{\circ} \mathrm{C}(29) . M$. flavus and the marine isolate, on the other hand, show long filamentous forms instead of the doughnut-like cells under certain cultural conditions. $M$. flavus gives rise to long "spaghetti-like" strings when grown in MR-VP medium, nutrient gelatin medium, or HL medium with glucose (29). Further studies reveal that doughnut cells on TGEY medium transform to long filamentous cells when 0.25 to $0.5 \% \mathrm{~K}_{2} \mathrm{HPO}_{4}$ is added. Similarly, when $\mathrm{K}_{2} \mathrm{HPO}_{4}$ is deleted from MR-VP medium, the spaghetti cells revert to doughnut cells.
Likewise, the doughnut cells of the marine isolate on TGEY medium plus $3.0 \% \mathrm{NaCl}$ are transformed to long sinuous forms when $\mathrm{NaCl}$ is deleted from the medium.

Cultural characteristics. The marine isolate produces pinkish, circular, convex, smooth, mucoid, opaque, viscid colonies of small size $(<2 \mathrm{~mm}$ in diameter) with an entire edge and a colorless, narrow peripheral zone when grown on $\mathrm{mZ}$ medium. Except for the medium size and yellowish pigment, $M$. flavus colonies on TGEY medium have the same characteristics as above for the marine isolate whereas $M$. aquaticus colonies on TGEY medium are circular, raised, opaque, butyrous, off-white, and medium-sized with a "fried-egg" contour (29). Like the yelloy pigment of $M$. flavus, the pinkish pigment produced by the marine isolate is insoluble in water but soluble in an acetone-ethanol mixture; 


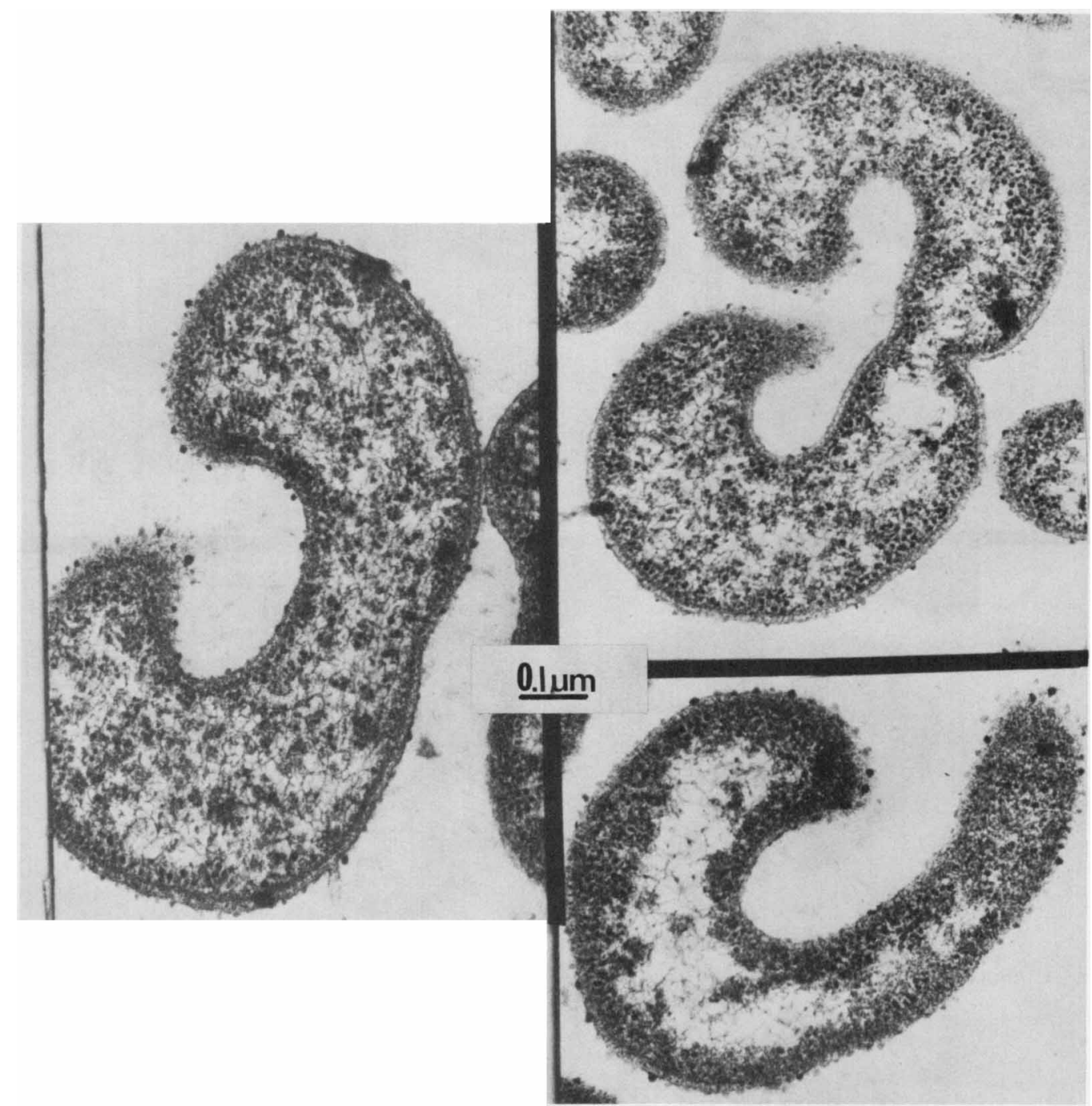

Fig. 2. Electron micrographs of thin sections of the marine isolate showing ring-like cells with indentations representing various stages of cell division.

furthermore, it is possibly carotenoid in nature. In their respective broth cultures, the marine isolate and $M$. flavus never form a ring growth around the container walls or pellicle over the medium surface but produce even turbidity and viscid sediment, whereas $M$. aquaticus gives rise to a pellicle, flocculent turbidity, and a flaky or stringy sediment.

Physiological characteristics. The three $M i$ crocyclus strains studied here grow optimally at room temperature $\left(20\right.$ to $\left.25^{\circ} \mathrm{C}\right)$, somewhat at $7^{\circ} \mathrm{C}$, and not at all at 37 or $45^{\circ} \mathrm{C}$. Also, they grow better with shaking than without. The $\mathrm{pH}$ for optimum growth of the marine isolate is around 7.6, and of $M$. flavus and $M$. aquaticus it is about 7.0. Whereas the marine isolate re- quires 1.5 to $3.0 \% \mathrm{NaCl}$ for growth, $M$. flavus and $M$. aquaticus can do without $\mathrm{NaCl}$. However, the former can tolerate up to $15.0 \% \mathrm{NaCl}$ whereas the latter grow only slightly in $3.0 \%$ $\mathrm{NaCl}$. All three organisms failed to grow in the presence of $5 \%$ or more sucrose. When tested for thermosensitivity, the marine isolate survived $10 \mathrm{~min}$ of exposure to $55^{\circ} \mathrm{C}$ somewhat better than the other two organisms; however, all three were sensitive to the higher temperatures employed. Whereas the marine isolate and $M$. aquaticus were sensitive to UV irradiation, $M$. flavus survived $1 \mathrm{~min}$ of exposure but not 3 min. The three organisms were quite sensitive to $70 \%$ ethanol, $3 \% \mathrm{H}_{2} \mathrm{O}_{2}$, and $0.1 \%$ Zepharin chloride. As shown in Table 3, the marine iso- 


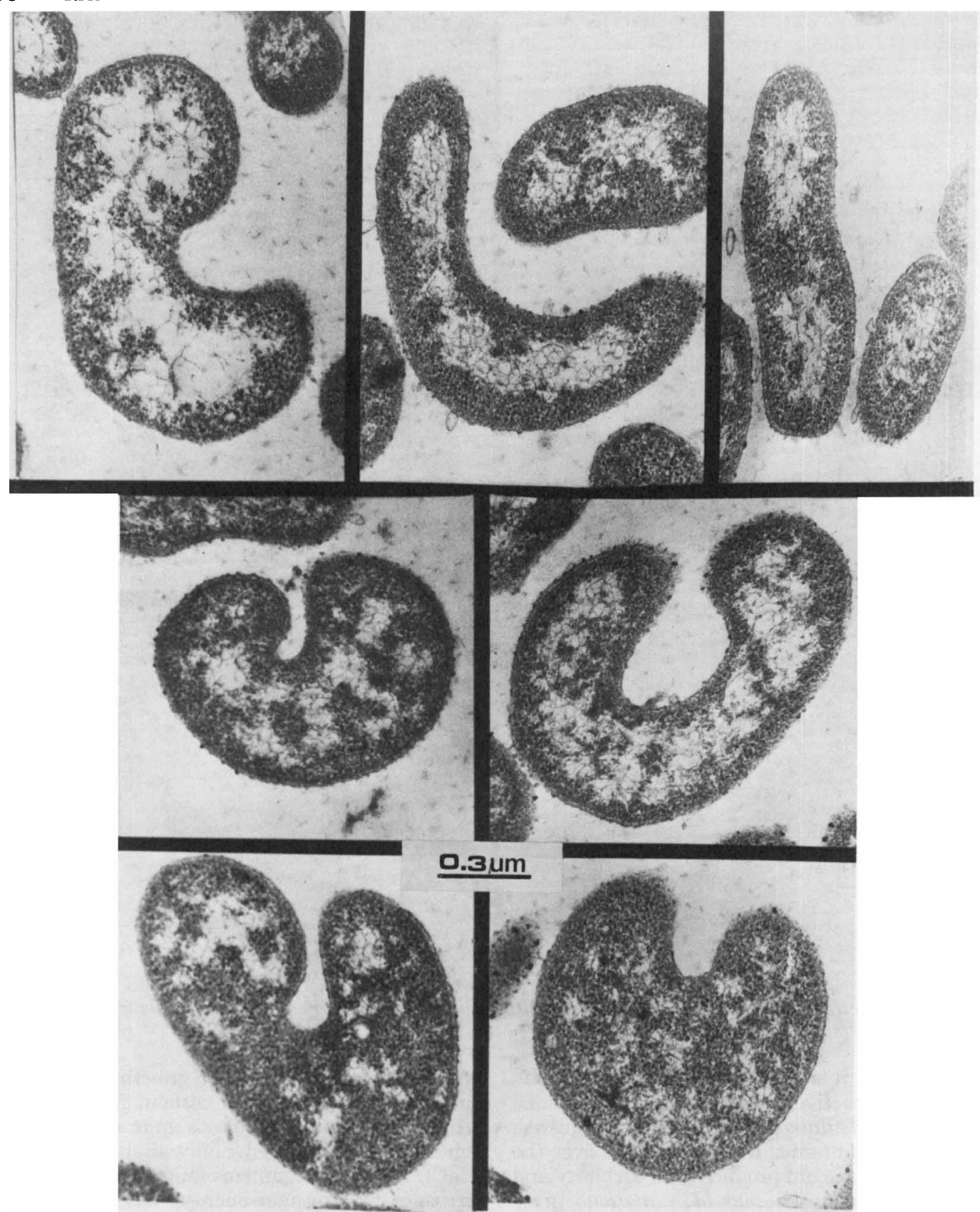

FIG. 3. Electron micrographs of thin sections of the marine isolate showing various morphogenic forms when grown on $m Z$ marine medium at room temperature.

late grows well on TGEY medium and various other commercially available media when fortified with $3 \% \mathrm{NaCl}$ and $0.03 \% \mathrm{~K}_{2} \mathrm{HPO}_{4}$. Similarly, $M$. aquaticus is not fastidious in its growth requirements whereas $M$. flavus grows only slightly in brain heart infusion and trypticase soy broths and not at all on eosin methylene blue and Lowenstein-Jensen agar media. The three organisms failed to grow in fluid thioglycolate medium. Some of the chemically 
defined media commercially available for tissue culture procedures, such as TC medium L15 and TC medium 199 (Difco), supported luxuriant growth of these organisms without any further enrichment except for the marine isolate, which required the addition of $3.0 \% \mathrm{NaCl}$ and $0.03 \% \mathrm{~K}_{2} \mathrm{HPO}_{4}$ to these media. In addition, the marine isolate grew very well in Brock synthetic seawater medium (4).

Of the 37 antibiotics and sulfonamides tested (see Table 4), the three organisms studied were susceptible to the following: ampicillin, cephalothin, erythromycin, furadantin, furadantin plus macrodantin, nalidixic acid, novobiocin, terramycin, and tetracycline $(30 \mu \mathrm{g})$; they were resistant to colymycin, methicillin, oxacillin, penicillin $\mathrm{G}$, polymyxin $\mathrm{B}$, sulfadiazine, and triple sulfa. In all, the marine isolate was susceptible to only 14 of the 37 antimicrobial agents tested, and it was extremely susceptible to erythromycin, furadantin, novobiocin, and oleandomycin. Similarly, $M$. aquaticus was susceptible to 18 agents, and it was extremely susceptible to declomycin, terramycin, tetracycline, and vibramycin. On the other hand, $M$. flavus was susceptible to 28 antimicrobial agents and was extremely susceptible to aureomycin, gantrisin, and sulfathiozole.

Biochemical characteristics. The three organisms failed to hydrolyze any of the polysaccharides tested or to produce indole, a positive methyl red reaction, acetyl-methylcarbinol, gelatin liquefaction, or $\mathrm{H}_{2} \mathrm{~S}$. However, they produced $\mathrm{NH}_{3}$ from peptone and possessed catalase and cytochrome oxidase (much weaker oxidase activity in $M$. flavus), but they lacked protease, reductase, urease, and hemolysin activities. Also, only $M$. aquaticus reduced $\mathrm{NO}_{3}$ to $\mathrm{NO}_{2}$ and $\mathrm{NH}_{3}$ and showed lipase activity. In litmus milk, $M$. aquaticus produced an alkaline reaction, soft curd, and peptonization; the marine isolate gave an acid reaction only; and $M$. flavus failed to cause any reaction. Of the 13 different carbon sources tested, $M$. flavus failed to oxidize any, whereas the marine isolate and $M$. aquaticus utilized acetate, citrate, malonate, pyruvate, and succinate. In addition, the marine isolate oxidized fumarate, malate, and tartrate, whereas $M$. aquaticus attacked formate, lactate, and oxaloacetate (see Table 5).

Of the 22 carbohydrates assayed (Table 5), the marine isolate oxidized $16, M$. flavus oxidized 13 , and $M$. aquaticus oxidized 12 ; acid but no gas was produced after 2 to 3 weeks of incubation at room temperature. Although none of the organisms attacked any of the carbohydrates fermentatively, they all oxidized arabinose, fructose, galactose, glucose, inulin, man- nose, melibiose, sucrose, and xylose; adonitol, dulcitol, glycerol, and inositol were not oxidized.

Radiorespirometric studies. Since carbohydrate metabolism proceeds sequentially through primary and secondary pathways of catabolism, radiorespirometric experiments were conducted to estimate the contribution of each of the primary pathways operating in the marine isolate. Table 6 shows the radiochemical recoveries of specifically labeled carbon atoms of glucose. Normalizing these recoveries to a total of $100 \%$ in each case of the specifically labeled carbons (i.e., recovery of ${ }^{14} \mathrm{C}$ from $\mathrm{CO}_{2}$, cells, and medium totaled to $100 \%$ ), it was calculated that ${ }^{14} \mathrm{CO}_{2}$ recovery of $\mathrm{C}_{1}=53 \%, \mathrm{C}_{2}=$ $46 \%, \mathrm{C}_{3}=67 \%, \mathrm{C}_{3,4}=69 \%$, and $\mathrm{C}_{6}=42 \%$; that of $\mathrm{C}_{4}$ separately was determined to be $71 \%$. Thus, the preferential oxidation of labeled carbons of glucose to ${ }^{14} \mathrm{CO}_{2}$ yielded a pattern: $\mathrm{C}_{4}>$ $\mathrm{C}_{3}>\mathrm{C}_{1}>\mathrm{C}_{2}>\mathrm{C}_{6}$ (Fig. 4). Since the respiratory recoveries of $\mathrm{C}_{3}$ and $\mathrm{C}_{4}$ are greater than those of the other carbons, the operation of the EM pathway in the marine isolate is very apparent. However, because $\mathrm{C}_{4}$ recovery should not be greater than that of $\mathrm{C}_{3}$, and $\mathrm{C}_{1}$ recovery should not exceed those of $\mathrm{C}_{2}$ and $\mathrm{C}_{6}$, via this pathway, the slightly greater recovery of $\mathrm{C}_{4}$ and $\mathrm{C}_{3}$ and of $\mathrm{C}_{1}$ than $\mathrm{C}_{2}$ and $\mathrm{C}_{6}$ seems to indicate some simultaneous participation of the $P P$ and/or ED pathways. It is estimated, therefore, that as much as $80 \%$ of the administered glucose is oxidized via the EM pathway, $13 \%$ is oxidized via the ED pathway, and 7\% is oxidized via the PP pathway. As shown in Table 6, the low yields of respiratory ${ }^{14} \mathrm{CO}_{2}$ from $\mathrm{C}_{6}$ and $\mathrm{C}_{1}$ as compared to those from $\mathrm{C}_{4}$ and $\mathrm{C}_{3}$ were compensated for by their proportionately higher cellular incorporations, and vice versa. As expected, there is a greater conservation of the methylcarbon atoms than the carboxyl carbons of pyruvates from glucose when oxidized via the tricarboxylic acid cycle for cellular biosynthesis. Contrary to the findings shown in Table 5, further radiorespirometric studies showed that the marine isolate utilized ${ }^{14} \mathrm{C}$-labeled acetate, gluconate, and pyruvate, producing varying amounts of ${ }^{14} \mathrm{CO}_{2}$ (unpublished data). Similar studies of $M$. flavus and $M$. aquaticus reported previously elsewhere (18) showed that $M$. flavus oxidizes as much as $96 \%$ of the administered glucose via the EM pathway and only $4 \%$ via the PP pathway, whereas $M$. aquaticus catabolizes $81 \%$ of the glucose via the ED pathway and the remaining glucose via the $\mathrm{PP}$ and EM pathways. Both of these bacteria showed evidence of the tricarboxylic acid cycle as a secondary pathway for the oxidation of carbo- 
TABLE 5. Biochemical characteristics of the strains studied ${ }^{a}$

\begin{tabular}{|c|c|c|c|}
\hline Chracteristic & $\begin{array}{c}\text { Marine isolate } \\
\text { ATCC } 25205 \\
\end{array}$ & $\begin{array}{c}M . \text { flavus } \\
\text { ATCC } 23276\end{array}$ & $\begin{array}{c}\text { M. aquaticus } \\
\text { ATCC } 25396\end{array}$ \\
\hline 141. Agar digestion & - & - & - \\
\hline 142. Chitin digestion & - & - & - \\
\hline 143. Cellulose digestion & - & - & - \\
\hline 144. Gelatin liquefaction & - & - & - \\
\hline 145. Starch hydrolysis & - & - & - \\
\hline 146. Litmus milk reduction & + & - & + \\
\hline 147. Litmus milk acid & + & - & - \\
\hline 148. Litmus milk alkaline & - & - & + \\
\hline 149. Litmus milk hard curd & - & - & - \\
\hline 150. Litmus milk soft curd & - & - & + \\
\hline 151. Litmus milk peptonization & - & - & + \\
\hline 152. $\mathrm{NO}_{3}$ reduction to $\mathrm{NO}_{2}$ & - & - & + \\
\hline 153. $\mathrm{NO}_{3}$ reduction to $\mathrm{NH}_{3}$ & - & - & + \\
\hline 154. $\mathrm{NO}_{3}$ reduction to $\mathrm{N}_{2}$ & - & - & - \\
\hline 155. $\mathrm{NH}_{3}$ from peptone water & + & + & + \\
\hline 156. Indole production & - & - & - \\
\hline 157. Methyl red reaction & - & - & - \\
\hline 158. Voges Proskauer reaction & - & - & - \\
\hline 159. $\mathrm{H}_{2} \mathrm{~S}$ from thiosulfate & - & - & - \\
\hline 160. Catalase & + & + & + \\
\hline 161. Oxidase & + & + & + \\
\hline 162. Reductase & - & - & - \\
\hline 163. Urease & - & - & - \\
\hline 164. Lipase & - & - & + \\
\hline 165. Hemolyyins & - & - & - \\
\hline 166. Proteases (casein hydrolysis) & - & - & - \\
\hline $\begin{array}{l}\text { 167. Guanine + cytosine content (mol\%) of DNA } \\
\text { base }\end{array}$ & 38.3 & 51.0 & 67.3 \\
\hline \multicolumn{4}{|l|}{ Utilization of various carbon sources: } \\
\hline 168. Acetate & + & $-b$ & + \\
\hline 169. Benzoate & - & - & - \\
\hline 170. Citrate & + & - & + \\
\hline 171. Formate & - & - & + \\
\hline 172. Fumarate & + & - & - \\
\hline 173. Gluconate & $-b$ & $-b$ & $-b$ \\
\hline 174. Lactate & - & - & + \\
\hline 175. Malate & + & - & - \\
\hline 176. Malonate & + & - & + \\
\hline 177. Oxaloacetate & - & - & + \\
\hline 178. Pyruvate & + & $-{ }^{b}$ & + \\
\hline 179. Succinate & + & - & + \\
\hline 180. Tartrate & + & - & - \\
\hline Utilization of various carbohydrates: & $\begin{array}{l}\text { (modified HL } \\
\text { medium) }\end{array}$ & (HL medium) & (HL medium) \\
\hline 181. Adonitol & - & - & - \\
\hline 182. Arabinose & A & A & A \\
\hline 183. Dulcitol & - & - & - \\
\hline 184. Fructose & A & A & A \\
\hline 185. Galactose & $\mathrm{A}$ & A & A \\
\hline 186. Glucose & A & $\mathrm{A}$ & A \\
\hline 187. Glycerol & - & - & - \\
\hline 188. Inulin & A & A & $\mathbf{A}$ \\
\hline 189. Inositol & - & - & - \\
\hline 190. Lactose & A & A & - \\
\hline 191. Maltose & A & $\mathbf{A}$ & - \\
\hline 192. Mannitol & - & - & A \\
\hline 193. Mannose & A & A & A \\
\hline
\end{tabular}


Table 5-Continued

\begin{tabular}{|c|c|c|c|}
\hline Characteristic & $\begin{array}{l}\text { Marine isolate } \\
\text { ATCC } 25205\end{array}$ & $\begin{array}{c}\text { M. flavus } \\
\text { ATCC } 23276 \\
\end{array}$ & $\begin{array}{r}M . \text { aquaticus } \\
\text { ATCC } 25396 \\
\end{array}$ \\
\hline 194. Melezitose & $\mathbf{A}$ & - & - \\
\hline 195. Melibiose & A & $\mathbf{A}$ & $\mathbf{A}$ \\
\hline 196. Raffinose & A & A & - \\
\hline 197. Rhamnose & A & - & - \\
\hline 198. Salicin & A & - & $\mathbf{A}$ \\
\hline 199. Sorbitol & - & - & A \\
\hline 200. Sucrose & $\mathbf{A}$ & $\mathbf{A}$ & A \\
\hline 201. Trehlose & A & $\mathrm{A}$ & - \\
\hline 202. Xylose & $\mathbf{A}$ & A & A \\
\hline $\begin{array}{l}\text { No. of total biochemical similarities with the marine } \\
\text { isolate }\end{array}$ & & 49 & 40 \\
\hline $\begin{array}{l}\text { No. of positive biochemical similarities with the } \\
\text { marine isolate }\end{array}$ & & 16 & 19 \\
\hline $\begin{array}{l}\text { No. of biochemical dissimilarities with the marine } \\
\text { isolate }\end{array}$ & & 13 & 22 \\
\hline
\end{tabular}

${ }^{a}$ Symbols: A, definite acid produced oxidatively in about 2 to 3 weeks; +, positive reaction; -, no reaction even after 60 days of incubation. Duplicate tubes overlaid with sterile mineral oil for fermentative reaction showed no reaction.

${ }^{b}$ Radiorespirometric studies showed that all the three organisms utilized ${ }^{14} \mathrm{C}$-labeled acetate, gluconate, and pyruvate individually in their respective growth media producing varying amounts of ${ }^{14} \mathrm{CO}_{2}\left({ }^{(18}\right.$; unpublished data).

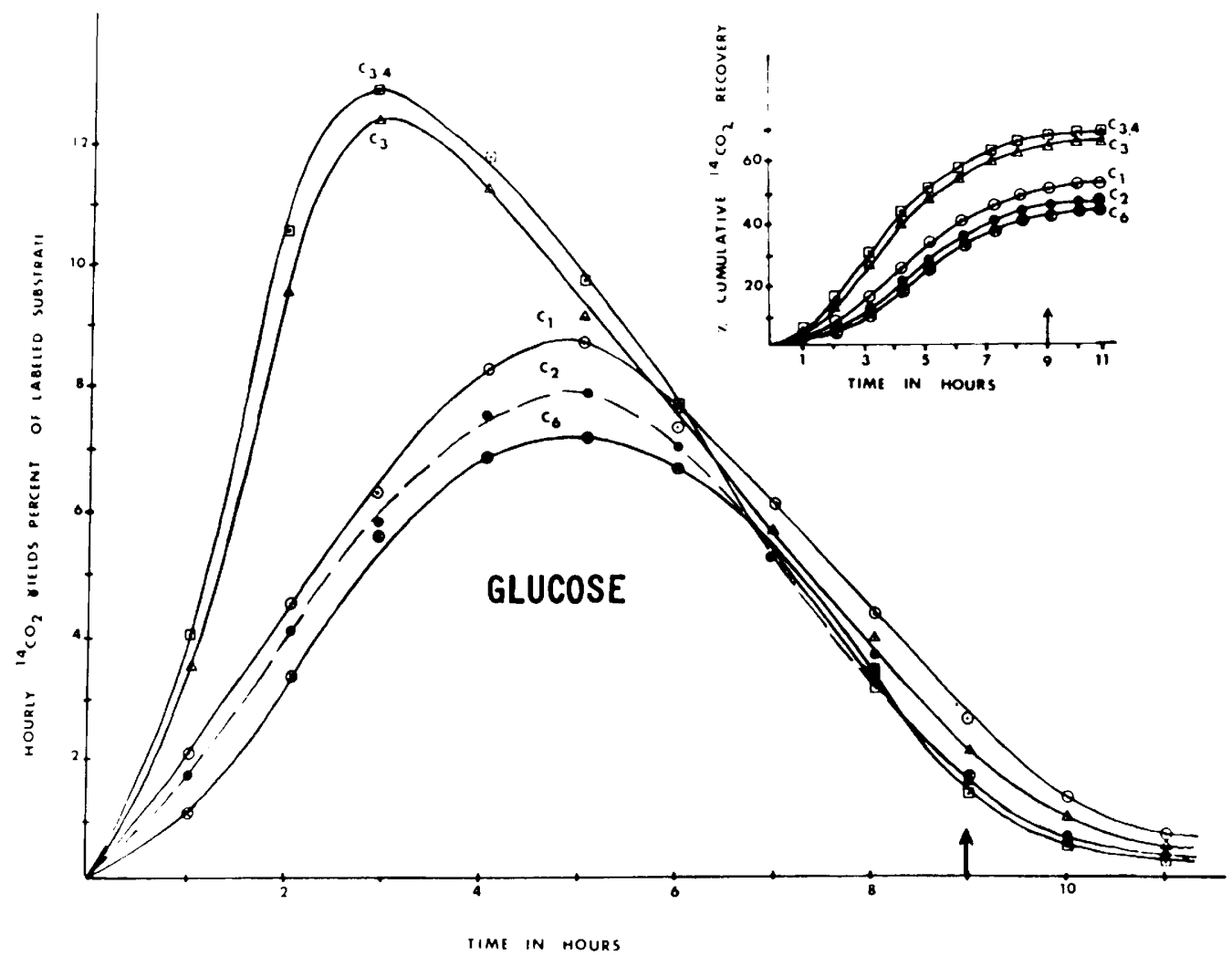

FIG. 4. Aerobic radiorespirometric patterns of glucose catabolism by the marine isolate. Arrow indicates a relative time unit of $9 \mathrm{~h}$ required by the organism to consume all of the intact labeled substrate originally added. 
TABLE 6. Utilization of $\left[{ }^{14} \mathrm{C}\right] \mathrm{glucose}$ by growing cells of the marine isolate

\begin{tabular}{lcccc}
\hline & \multicolumn{3}{c}{ Radiochemical inventory } \\
\cline { 2 - 4 } Substrate & $\mathrm{CO}_{2}$ & Cells & $\begin{array}{c}\text { Me- } \\
\text { dium }\end{array}$ & $\begin{array}{c}\text { Total } \\
{ }^{14} \text { C re- } \\
\text { covery }\end{array}$ \\
\hline$\left[1-{ }^{14} \mathrm{C}\right]$ glucose & 51 & 28 & 17 & 96 \\
{$\left[2-{ }^{14} \mathrm{C}\right]$ glucose } & 45 & 33 & 20 & 98 \\
{$\left[3-{ }^{14} \mathrm{C}\right]$ glucose } & 66 & 16 & 17 & 99 \\
{$\left[3,4-{ }^{14}\right.$ C $]$ glucose } & 68 & 17 & 13 & 98 \\
{$\left[6-{ }^{14} \mathrm{C}\right]$ glucose } & 42 & 35 & 22 & 99 \\
\hline
\end{tabular}

${ }^{a}$ Determined at end of experiment. All radiochemical recoveries ( $\mathrm{CO}_{2}$, cells, and medium) were first calculated to a total of $100 \%$ in each case. Then, the normalized ${ }^{14} \mathrm{CO}_{2}$ recoveries were used to estimate the relative percent contribution of each catabolic pathway, as per the formulas shown in the text.

hydrates. Furthermore, both catabolized ${ }^{14} \mathrm{C}$ labeled acetate, gluconate, and pyruvate, yielding respiratory ${ }^{14} \mathrm{CO}_{2}$.

\section{DISCUSSION}

In this study, the marine microcyclus was extensively compared with strains of the currently recognized Microcyclus species (Tables 1 to 5). A total of 202 characteristics was recorded for each organism: $10 \%$ of these were morphological, $20 \%$ were cultural, $40 \%$ were physiological, and $30 \%$ were biochemical features. On the basis of the characteristics shared under each category, the marine isolate was found to be similar 87 and 59\% morphologically, 90 and $70 \%$ culturally, 60 and $70 \%$ physiologically, and 80 and $66 \%$ biochemically to $M$. flavus ATCC 23276 and $M$. aquaticus ATCC 25396, respectively. In all, the marine strain shared a total of 149 (60 positive and 89 negative) features with $M$. flavus ATCC 23276 and 131 (53 positive and 78 negative) features with $M$. aquaticus ATCC 25396. This accounts for the marine isolate having, at best, $74 \%$ cross-relation with $M$. flavus and $65 \%$ with $M$. aquaticus. Applying the Adansonian principles of numerical taxonomy and using Sneath's equation (31) for the similarity index (S-value) on the basis of only positive features shared by the marine isolate, the $S$-value with $M$. flavus is calculated to be about $53 \%$; with $M$. aquaticus it is about $43 \%$. Since these percent similarities are far below the minimal values expected of strains within the same species (20), it seems that the marine isolate does not belong to either of the two currently recognized Microcyclus species. However, an S-value of 43 to $53 \%$ seems significant enough to justify separate-species status for the marine Microcyclus. It was on the basis of the same considerations that $M$. flavus, which, in agreement with a previous report (28), shows here only a $67 \%$ cross-relation having a $46 \% \mathrm{~S}$ value with the type species, $M$. aquaticus, was proposed and recognized as a separate species $(5,29)$.

Thus, the marine isolate is here regarded as belonging to a new species, for which the name Microcyclus marinus is proposed (ma.ri'nus. L. adj. marinus of the sea, marine). (It should be noted here that the marine isolate was tentatively named Microcyclus marinus by the author in 1970 [29]; however, the name was not validly published at that time, and it therefore has no standing in nomenclature. The present proposal of the name $M$. marinus does meet the current requirements for the valid publication of a species name as given in the Bacteriological Code [19].) The type strain of this species has been deposited in the American Type Culture Collection, Rockville, Md., under the number 25205 and in the Deutsche Sammlung von Mikroorganismen Collection under the number 745. The description given above for the marine isolate serves as the description for both the species $M$. marinus and the type strain. Obviously, the species description will have to be expanded as additional strains of this organism are isolated and described.

The characters useful in differentiating $M$. marinus from $M$. aquaticus and $M$. flavus are given in Table 7. Similarly, $M$. marinus is readily differentiated from $M$. major by morphological, cultural, physiological, and biochemical characteristics; for example, compared to the small size of $M$. marinus (doughnut cells having 0.8 to $1.5 \mu \mathrm{m}$ outer diameter and 0.3 to $0.7 \mu \mathrm{m}$ width), $M$. major ring-like cells have a 5- to $10-\mu \mathrm{m}$ outer diameter and 1- to $2-\mu \mathrm{m}$ width. Also, whereas the former occurs occasionally as straight or curved rods 1 to 5 $\mu \mathrm{m}$ long, the latter shows the same forms 5 to $50 \mu \mathrm{m}$ or more in length. Moreover, unlike $M$. marinus, $M$. major grows in some media as slightly bent rods with pointed ends and with age produces fiber-shaped (filamentous) structures several tens of micrometers in length and other bizarre shapes and involuted forms (7). Culturally, $M$. marinus grows on a seawater agar medium producing smooth, circular, mucoid, opaque, viscid, pink-pigmented, smallsized ( $<2 \mathrm{~mm}$ in diameter), convex colonies, whereas $M$. major grows on a freshwater agar medium giving rise to pale rose, round, shiny, transparent, large-sized (up to $0.5 \mathrm{~cm}$ in diameter), convex colonies. Also, unlike M. marinus, an older inoculum of $M$. major forms smaller $(0.2 \mathrm{~cm}$ in diameter), dull, and orange-colored 
TABLE 7. Characters useful in differentiating among the Microcyclus species studied

\begin{tabular}{|c|c|c|c|}
\hline Character & M. marinus & $M$. flavus & M. aquaticus \\
\hline \multirow[t]{2}{*}{$\begin{array}{l}\text { Morpho- } \\
\text { logical }\end{array}$} & $\begin{array}{l}\text { Mostly rings and horseshoes } \\
\left(0.8-1.5 \mu \mathrm{m} \mathrm{OD}^{a}\right) ; \text { some } \\
\text { coil or spiral forms }\end{array}$ & $\begin{array}{l}\text { Mostly rings and horseshoes } \\
(1.5-3.0 \mu \mathrm{m} \text { OD); some coil } \\
\text { or spiral forms }\end{array}$ & $\begin{array}{l}\text { Mostly vibrioid cells }(0.4-0.7 \\
\text { by } 1.0-3.0 \mu \mathrm{m}) ; \text { rings not } \\
\text { common. Coils, spirals, } \\
\text { and long strings not seen }\end{array}$ \\
\hline & $\begin{array}{l}\text { Long sinous strings in } \mathrm{NaCl}- \\
\text { deficient media }\end{array}$ & $\begin{array}{l}\text { Long "spaghetti" strings in } \\
\mathrm{K}_{2} \mathrm{HPO}_{4} \text { media }\end{array}$ & $\begin{array}{l}\text { Gas vacuoles produced by all } \\
\text { known strains; usually } \\
\text { nonmotile but a flagellated } \\
\text { variant has recently been } \\
\text { found }\end{array}$ \\
\hline
\end{tabular}

No gas vacuoles, flagella, or motility

Cultural

Small (2 $\mathrm{mm}$ in diameter), pinkish, mucoid, opaque, smooth, and convex colonies

Even turbidity and viscid sediment but no pellicle in broth cultures

Physiological

Metabolic

Litmus milk, lipids, and $\mathrm{NO}_{3}$ not attacked

Malate or tartrate but not formate, lactate, or oxaloacetate utilized as sole carbon source

Oxidatively, acid produced from lactose, maltose, melezitose, raffinose, rhamnose, and salicin but not from mannitol or sorbitol

Glucose catabolized mainly via the EM-tricarboxylic acid pathways with some via the PP and ED pathways

\section{$\mathrm{G}+\mathrm{C} \quad 38.3 \mathrm{~mol} \%$} content
No gas vacuoles, flagella, or motility

Medium-sized (2-5 $\mathrm{mm}$ in diameter), yellowish, mucoid, opaque, smooth, and convex colonies

Even turbidity and viscid sediment but no pellicle in broth cultures

$\mathrm{NaCl}$ not required for growth; can tolerate up to $3 \% \mathrm{NaCl}$. Susceptible to bacitracin, elkosin, gantrisin, sulfamerazine, sulfamethoxypyridazine, and thiosulfil

Litmus milk, lipids, and $\mathrm{NO}_{3}$ not attacked

Formate, lactate, malate, oxaloacetate and tartrate not utilized as sole carbon source

Oxidatively, acid produced from lactose, maltose, and raffinose but not from melezitose, mannitol, salicin, rhamnose, or sorbitol

Glucose catabolized mainly via the EM-tricarboxylic acid pathways with a little via the $P P$ pathway and none via the ED pathway
Medium-sized (2-5 $\mathrm{mm}$ in diameter), off-white, dull, mucoid, opaque, raised, and contoured colonies

Pellicle, flocculent turbidity, and flaky sediment in broth cultures

$\mathrm{NaCl}$ not required for growth; can tolerate up to $3 \% \mathrm{NaCl}$; susceptible to neomycin and resistant to chloramphenicol, oleandomycin, ristocetin, and sulfathiozole

Litmus milk rendered alkaline and peptonized; $\mathrm{NO}_{3}$ reduced to $\mathrm{NO}_{2}$ or $\mathrm{NH}_{3} ; \mathrm{Li}$ pase present

Formate, lactate, and oxaloacetate but not malate or tartrate utilized as sole carbon source

Oxidatively, acid produced from mannitol, salicin, and sorbitol but not from lactose, maltose, melezitose, raffinose, or rhamnose

Glucose catabolized mainly via the ED-tricarboxylic acid pathways with some via the PP and EM pathways

\footnotetext{
a OD, Outer diameter.
} 
colonies with wrinkled surface and wavy edge. In a seawater broth medium, $M$. marinus produces even turbidity and viscid sediment but never ring-growth around the container walls or pellicle over the broth surface. $M$. major, on the other hand, in a freshwater broth medium yields cottony-growth on the broth surface which easily sinks to the bottom and forms a flocculent precipitate (12). Although physiological as well as metabolic studies made of $M$. major to date are quite inadeqaute (12), it seems that, unlike $M$. marinus, the former hydrolyzes starch, reduces methylene blue, liquefies gelatin slightly, and fails to attack litmus milk, rhamnose, or xylose. Also, no thorough taxonomic studies have yet been made of $M$. major. Even though both $M$. marinus and $M$. major have been shown (8) to have similar G + C contents (38.3 to $39.7 \mathrm{~mol} \%), M$. major, because of its large size and pointed ends, its spiral forms, and other characters noted above, has been thought to be a nonmotile variant of a Spirillum sp. or possibly closely related to some blue-green algae which characteristically form spiral structures (7). Also, it has been suggested that this organism should be considered to be a flavobacterium (7).

It may be noted that the DNA base compositions of these organisms vary significantly (see Table 7). Using this as a sole parameter of genetic similarity, Claus et al. (8) proposed classifying $M$. aquaticus, $M$. flavus and Spirosoma, and $M$. major into three separate genera and suggested that ring formation (i.e., cell morphology) is not a sufficiently restrictive criterion to justify delineation of a genus. If, indeed, the characteristic morphology is overlooked and the DNA base composition is the only taxonomic determinant, then these bacteria could very well be included in the genus Desulfovibrio, Flavobacterium, Pseudomonas, Spirillum, or Vibrio (14). By the same token, if both gross morphology and DNA base composition were the only criteria for bacterial classification, then these Microcyclus organisms would belong to the genus Spirillum or Vibrio (10). The variation noted in the $\mathrm{G}+\mathrm{C}$ contents of these $\mathrm{Mi}$ crocyclus species is not uncommon among species within the same genus and even among strains of the same species. For example, the DNA base composition of 28 strains of Desulfovibrio desulfuricans is shown to vary from 44 to $65 \mathrm{~mol} \%$ (14).

DNA base homology has been used in the molecular taxonomy of a number of microbial groups (21). Recently, Konopka et al. (personal communication, 1975) studied the DNA heteroduplex formation as well as the $\mathrm{G}+\mathrm{C}$ content of Microcyclus species and other ring-forming bacteria. They found that the marine isolate (M. marinus) and $M$. flavus are genetically unrelated to $M$. aquaticus (duplex formation of 0 to $4 \%$ at $73^{\circ} \mathrm{C}$ ) and, therefore, they proposed that these three bacteria should represent three different genera. Furthermore, these authors identified, mostly on the basis of G + C content, five gas-vacuolated isolates as belonging to the type species, M. aquaticus, and two Spirosoma isolates as belonging to $M$. flavus, even though the DNA base homology failed to show significant genetic relatedness expected of strains of one species; for example, under their experimental conditions, the heteroduplex formation was only 28 to $45 \%$ among the former group and 24 to $38 \%$ among the latter. In contrast, similar studies of 30 strains of Escherichia coli yielded a base-sequence complementarity of 78 to $100 \%$ (3). However, the degree of interspecific DNA reassociation and the stability of the heteroduplexes can vary greatly with different experimental conditions, such as differences in binding temperature and ionic strength $(2,3$, 6). Another approach to classification based on genetic similarity and evolutionary relationships is the comparison of homologous proteins of closely related organisms, according to which it is expected that, among members of any one species, particular enzymes would display similar electrophoretic behavior; nevertheless, variations have been noted in the electrophoretic mobilities of the lactic dehydrogenases of otherwise closely related organisms (23). Similarly, various strains of Leucothrix mucor that were quite similar in their morphological, nutritional, and physiological characteristics as well as in DNA base composition were found to contain malate and isocitrate dehydrogenases with heterogeneous electrophoretic properties (16). There are several ways in which electrophoretic differences may not be due to changes in the genetic material (23); however, it is possible that a single mutational event causing a change in the amino acid composition can alter the electrophoretic mobility of a homologous protein.

It is reasonable to presume that the interactions observed at the molecular level, such as DNA reassociations, reflect genetic and phylogenetic relationships among related organisms. However, in the absence of any formal guidelines, any attempt to derive taxonomic conclusions from genetic and molecular data alone is considered premature and certainly arbitrary $(2,6)$. By the same token, it is realized that basing the relatedness on phenetic data alone suffers from certain taxonomic limitations (33). Sneath and Sokal (32) suggested the use of the term "phenon" per se in the numerical taxon- 
omy of bacteria without necessarily equating phenons with species, genus, etc. Cowan (9), in fact, questioned the validity of the species concept in bacteria. However, studies of polyphasic taxonomy complementing numerical taxonomy with polynucleotide sequence relationships have been favored by some workers $(2,3,6)$. Although the polyphasic approach has shown a high correlation between the two methods in most cases, it has failed to resolve a few baffling sets of data: for example, the case of $E$. coli 0128 a versus Shigella flexneri 24570 , with an Svalue of only $59 \%$ but a DNA reassociation relationship of $80 \%$ at $75^{\circ} \mathrm{C}$ and, conversely, the case of $E$. coli 0128 a versus Salmonella typhimurium LT2, with an S-value of $71.3 \%$ but a DNA duplex formation of only $12 \%$ at $75^{\circ} \mathrm{C}(3)$; similarly, the case of Vibrio cholerae versus $V$. parahaemolyticus, with interspecies S-values of 66 to $75 \%, \mathrm{G}+\mathrm{C}$ contents of 46 to $48 \mathrm{~mol} \%$, but a relative DNA reassociation of only 0 to $5 \%$ at $75^{\circ} \mathrm{C}$. Although the low levels of genetic relatedness between the two Vibrio species apparently justify separate genus status for each, the retention of $V$. parahaemolyticus within the genus Vibrio was recommended as a cautious and more practical assessment of all the data on hand, and additional research was suggested (6). Similarly, although separate genus status could be justified for $M$. marinus, it seems more pragmatic at this time to recognize it as a separate species within the genus Microcyclus. This would be consistent with the recent judgement giving separate species status to $M$. aquaticus, $M$. flavus, and $M$. major (5). Clearly, an extensive comparative study, phenetic as well as genetic, is needed of all Microcyclus and related ring-forming organisms to better establish their taxonomic status.

\section{ACKNOWLEDGMENTS}

I thank Richard L. Weiss, The Biological Laboratories, Harvard University, Cambridge, Mass., for doing the electron microscopy of $M$. marinus and $M$. Mandel, Department of Molecular Biology, M. D. Anderson Hospital and Tumor Institute, University of Texas, Houston, Tex., for determining the DNA base compositions.

This research was supported by institutional faculty research grant no. 212-138 from the National Science Foundation.

\section{LITERATURE CITED}

1. Bayer, M. E. 1967. Response of cell walls of Escherichia coli to a sudden reduction of the environmental osmotic pressure. J. Bacteriol. 73:365-375.

2. Brenner, D. J., G. R. Fanning, K. E. Johnson, R. V. Citarella, and S. Falkow. 1969. Polynucleotide sequence relationships among members of Enterobacteriaceae. J. Bacteriol. 98:637-650.

3. Brenner, D. J., G. R. Fanning, F. J. Skerman, and S. Falkow. 1972. Polynucleotide sequence divergence among strains of Escherichia coli and closely related organsisms. J. Bacteriol. 109:953-965.
4. Brock, T. D. 1964. Knots in Leucothrix mucor. Science 144:870-872.

5. Buchanan, R. E., and N. E. Gibbons. 1974. Bergey's manual of determinative bacteriology, 8 th ed. The Williams and Wilkins Co., Baltimore.

6. Citarella, R. V., and R. R. Colwell. 1970. Polyphasic taxonomy of the genus Vibrio: polynucleotide sequence relationships among selected Vibrio species. J. Bacteriol. 104:434-442.

7. Claus, D. 1967. Taxonomy of some highly pleomorphic bacteria. Spisy Priorodoved. Fak. Univ. J. E. Purkyne Brno K40:254-257.

8. Claus, D., J. E. Bergendahl, and M. Mandel. 1968. DNA base composition of Microcyclus species and organisms of similar morphology. Arch. Mikrobiol. 63:26-28.

9. Cowan, S. T. 1962. The species-a macromyth. Microbial classification. Symp. Soc. Gen. Microbiol. 12:433-455

10. De Ley, J. 1964. Pseudomonas and related genera. Annu. Rev. Microbiol. 18:17-46.

11. Gilleland, H. E., Jr., and R. G. E. Murray. 1975. Demonstration of cell division by septation in a variety of gram-negative rods. J. Bacteriol. 121:721-725.

12. Gromov, B. V. 1963. A new bacterium of the genus Microcyclus. Dokl. Akad. Nauk. SSSR 152:733-734.

13. Hallock, F. A. 1960. The life cycle of Vibrio alternans (sp. nov.). Trans. Am. Micros. Soc. 79:404-411.

14. Hill, L. R. 1966. An index to deoxyribonucleic acid base composition of bacterial species. J. Gen. Microbiol. 44:419-437.

15. Hugh, R., and E. Leifson. 1953. The taxonomic significance of fermentative versus oxidative metabolism of carbohydrates by various gram-negative bacteria. J. Bacteriol. 66:24-26.

16. Kelly, M. T., and T. D. Brock. 1969. Molecular heterogeneity of isolates of marine bacterium Leucothrix mucor. J. Bacteriol. 100:14-21.

17. Konopka, A. E., J. T. Staley, and J. C. Lara. 1975. Gas vesicle assembly in Microcyclus aquaticus. J. Bacteriol. 122:1301-1309.

18. Kottel, R. H., and H. D. Raj. 1973. Pathways of carbohydrate metabolism in Microcyclus species. J. Bacteriol. 113:341-349.

19. Lapage, S. P., P. H. A. Sneath, E. F. Lessel, V. B. D. Skerman, H. P. R. Seeliger, and W. A. Clark (ed.) 1975. Bacteriological code. American Society for Microbiology, Washington, D.C.

20. Liston, J., W. J. Wiebe, and R. R. Colwell. 1963. Quantitative approach to the study of bacterial species. J. Bacteriol. 85:1061-1070.

21. McCarthy, B. J. 1967. Arrangement of base sequences in deoxyribonucleic acid. Bacteriol. Rev. 31:215-229.

22. Mandel, M. 1966. Deoxyribonucleic acid base composition in the genus Pseudomonas. J. Gen. Microbiol. 43:273-292.

23. Markert, C. L. 1968. Molecular basis for isozymes. Ann N. Y. Acad. Sci. 151:14-40.

24. Migula, W. 1894. Über ein neues system der bakterien. Arb. Bakteriol. Inst. Karlsruhe 1:235-238.

25. Migula, W. 1900. System der Bakterien. Handbuch der Morphologie Entwickelungsgeschichte und Systematik der Bakterien 2:955-960.

26. Nikitin, D. I. 1971. A new soil microorganism-Renobacter vacuolatum. Gen, et sp. n. Dokl. Adak. Nauk. SSSR 198:447-448.

27. Orskov, J. 1928. Beschreibung eines neuen mikroben, Microcyclus aquaticus, mit eigentümlicher morphologie. Zentralbl. Bakteriol. Parasitenk. Infektionskr. Hyg. Abt. 1 107:180-184.

28. Raj, H. D. 1967. Radiorespirometric studies of Leucothrix mucor. J. Bacteriol. 94:615-623.

29. Raj, H. D. 1970. A new species: Microcyclus flavus. Int. J. Syst. Bacteriol. 20:61-81. 
30. Sieburth, J. M., H. L. Pratt, P. W. Johnson, and D. Scales. 1975. Microbial seascapes - a pictorial essay of marine microorganisms and their environments. University Park Press, Baltimore.

31. Sneath, P. H. A. 1957. The application of computers to taxonomy. J. Gen. Microbiol. 17:201-226.

32. Sneath, P. H. A., and R. R. Sokal. 1962. Numerical taxonomy. Nature (London) 193:855-860.

33. Sokal, R. R., and P. H. A. Sneath. 1963. Principles of numerical taxonomy. W. H. Freeman and Co., San
Francisco.

34. Van Ert, M., and J. T. Staley. 1971. Gas vacuolated strains of Microcyclus aquaticus. J. Bacteriol. 108:236-240.

35. Weibel, E. 1887. Untersuchungen über vibrionen. Zentralbl. Bakteriol. Parasitenk. Infektionskr. Hyg. Abt. 1 16:465-472.

36. Wiebe, W. J., and G. B. Chapman. 1968. Fine structure of selected marine pseudomonads and achromobacters. J. Bacteriol. 95:1862-1873. 